\title{
PREEMBRYO PERSONHOOD: AN ASSESSMENT OF THE PRESIDENT'S COUNCIL ARGUMENTS
}

\begin{abstract}
The President's Council on Bioethics has addressed the moral status of human preembryos in its reports on stem cell research and human therapeutic cloning. Although the Council has been criticized for being hand-picked to favor the right-to-life viewpoint concerning human preembryos, it has embraced the idea that the right-to-life position should be defended in secular terms. This is an important feature of the Council's work, and it demonstrates a recognition of the need for genuine engagement between opposing sides in the debate over stem cell research. To promote this engagement, the Council has stated in secular terms several arguments for the personhood of human preembryos. This essay presents and critiques those arguments, and it concludes that they are unsuccessful. If the best arguments in support of the personhood of human preembryos have been presented by the Council, then there are no reasonable secular arguments in support of that view.
\end{abstract}

KEY WORDS: embryo, essential property, moral standing, personhood, preembryo, President's Council on Bioethics, stem cell, substantial identity, therapeutic cloning

Controversy over stem cell research arises from the fact that obtaining stem cells involves destruction of human preembryos. ${ }^{1}$ Some maintain that human preembryos have full moral standing and that killing them is murder. Others hold either that preembryos have no moral standing or that they have an intermediate status that permits their destruction in at least some circumstances. Those who regard preembryos as persons often base this view on religious beliefs. The question arises as to how, in our pluralistic culture, we should arrive at public policy concerning this contentious issue. One approach is to strive for genuine engagement between the opposing factions, an engagement in which each side presents arguments and is open to their critique. ${ }^{2}$ Although the President's Council on Bioethics has been criticized for being stacked in favor of the right-to-life viewpoint, ${ }^{3}$ it has promoted engagement by setting forth several arguments, stated in secular terms, in defense of the view that preembryos are persons. In doing so, it has endorsed the idea that all 
sides, including those who regard preembryos as persons, should give arguments and that public policy formation should be approached through critical examination of opposing arguments. In this paper, I shall attempt to state and critique the arguments the Council has presented.

Two main arguments can be found, one of which is presented in Monitoring Stem Cell Research. This report claims not to be advocating the various arguments it presents, including the argument in question. As the report states:

...our purpose is not finally to assess the validity of the competing claims or to arrive at a conclusion, but - in line with the Council's charge to monitor developments in this area-to present them more or less as they have appeared in the public debates of the past several years. ${ }^{4}$

In Human Cloning and Human Dignity, a second argument can be found, not in the body of the report, but in a personal statement in an appendix. Most of the Council members wrote a personal statement that was attached to the end of the report. The statement in question was authored by Robert P. George and joined by Alfonso GómezLobo. ${ }^{5}$ Again, the Council as a whole should not be regarded as advocating the argument in question, although it is clear that George and Gómez-Lobo support it. Each of these arguments will be considered in turn.

\section{THE ARGUMENT FROM IDENTITY THROUGH BIOLOGICAL CONTINUITY}

The argument in the stem cell report claims that there is identity between a preembryo and the adult who develops from that preembryo and that the identity is based on the continuity of the developmental process. I shall call it the argument based on identity through biological continuity. The report states:

Many of those who seek to defend human embryos base their case on some form of the argument for biological continuity and sameness through time. ...Every adult human being around us, they argue, is the same individual who, at an earlier stage of life, was a human embryo. ${ }^{6}$

The argument concludes that personhood begins with fertilization, based in part on the view that there is no point during development following fertilization at which it is reasonable to claim that the 
organism changes from nonperson to person. Thus, the report goes on to state:

This view holds that only the very beginning of a new (embryonic) life can serve as a reasonable boundary line in according moral worth to a human organism, because it is the moment marked out by nature for the first visible appearance in the world of a new individual. Before fertilization, no new individual exists. After it, sperm and egg cells are gone - subsumed and transformed into a new, third entity capable of its own internally self-directed development. ...

All further stages and events in embryological development, they argue, are discrete labels applied to an organism that is persistently itself even as it continuously changes in its dimensions, scope, degree of differentiation, and so on. ...

...[I]n the view of these commentators no discrete point in time or development would seem to give any justification for assuming that the embryo in question was one thing at one point and then suddenly became something different (turning, for example, from non-human to human or from non-person to person). ${ }^{7}$

For the purpose of critically examining the argument, it will be helpful to lay out its main premises and conclusion. I suggest that they can reasonably be stated as follows:

(1) Either personhood begins with fertilization or there is a change in identity during development after fertilization. ${ }^{8}$

(2) If there is a change in identity during development after fertilization, then there is a discrete point in time or development after fertilization at which a change in identity suddenly occurs.

(3) There is no discrete point in time or development after fertilization at which a change in identity suddenly occurs.

(2), (3), therefore:

(4) There is no change in identity during development after fertilization.

(1), (4), therefore:

(5) Personhood begins with fertilization.

\section{Critique}

Let me begin my critique by noting what seems quite plausible in the argument. Many would agree that premise (3) is true. Even among those who hold that personhood requires the acquisition of some characteristic, or set of characteristics, during development (e.g., sentience, brain activity, or self-consciousness, among other possibilities), many would agree that the relevant characteristic or set does 
not arise suddenly at some distinct point. I shall not take issue with the claim that there is no discontinuity of this sort.

There are, however, some problems with the argument. Some might find fault with premise (1). That premise assumes that if there is a change from nonperson to person during development, then there is a change in identity. In reply, an alternative view is that the organism can become a person without changing its identity. The issue in question can be described using the distinction between a "phase sortal" and a "proper sortal." A sortal is a predicate that tells us the type of thing an entity is. A phase sortal is a characteristic that an entity has during a stage of its existence. ${ }^{9}$ A standard example is "adolescent." A proper sortal tells us what an entity is throughout its existence. It is a matter of debate as to whether personhood is a phase sortal or a proper sortal. Some have defended the view that personhood is a phase sortal, and presumably they would reject premise (1). ${ }^{10}$ I shall not pursue that line of criticism here because it is even more clear that there is a serious difficulty with premise (2). It should be noted, however, that premise (1) makes a rather significant undefended assumption. In the remainder of my discussion of the argument from identity through biological continuity, I shall accept the assumption, for sake of argument, that a change from nonperson to person would involve a change in identity.

Premise (2) claims that any change in identity must occur suddenly, at a discrete point in time or development. In reply, an alternative view is that change in identity can occur gradually and continuously over time. Specifically, many hold that personhood is acquired later in development, with the acquisition of some characteristic or set of characteristics that develops gradually and continuously, as opposed to arising suddenly at a discrete point. On the assumption that a change from nonperson to person is a change in identity, this would be a gradual change in identity. Moreover, there seems to be no plausible reason to reject the view that an entity can change into something else gradually. Consider, for example, the fact that a small mound of iron filings can gradually become a mound of iron oxide, or rust. It would be reasonable to hold that when this happens, a change in identity occurs; after all, iron is not identical to iron oxide because the two types of substances have different chemical compositions. Furthermore, there is no nonarbitrary point in time that can be identified as "the point at which the mound changed from iron filings to rust." The same can be said concerning a biological entity's changing from one stage of development to another, 
without change in identity. For example, a human embryo changes into a fetus, but there is no discrete point in time or development at which this suddenly occurs. If there can be a gradual change from one stage of an entity to another, why cannot there be a gradual change from being one entity to being a different entity? The fact is, we have a clear intuition that an entity can come into being gradually. As Warren Quinn puts it:

...[T]he coming to be of a new individual is the passive equivalent of the making process. If a builder's making a house or mother nature's making a human being are genuine processes taking time then so too are the coming to be of a house or human being. ${ }^{11}$

If a house-under-construction can gradually become a house, then why cannot a developing human organism gradually become a human being, or gradually become a person?

It might be objected that if coming into existence is a gradual process, then we do not have a good way to describe the ontological status of the entity during the process. Does it partially exist? Does it not yet exist? If it partially exists, how are we to make sense of partial existence? If it does not yet exist, when does it begin to exist? ${ }^{12}$ In reply, the fact that one can raise puzzling questions is no grounds for denying the reality that gives rise to the questions. For example, puzzling questions can be raised about the relationship between mind and body. Do physical events in the brain cause mental events? If so, how? Are mental events identical to physical events? A lack of consensus concerning the answers to these questions is no reason to deny that there is a close relationship of some sort between physical events and mental events. Moreover, similar puzzling questions can be raised in regard to something as mundane as house building. Is a house-under-construction a house that has partial existence? If not, when does the house begin to exist? If there is no obvious answer to these questions, that is not a reason to hold that houses do not come into existence gradually. The idea that houses suddenly come into existence would be absurd (especially to those who have dealt with house builders).

In summary, the argument from identity through biological continuity claims that if the developing organism changes from nonperson to person following fertilization, then there must be a change in identity that occurs at a specific point in time or development. In reply, I have pointed out that the argument has not defended its assumption that a change from nonperson to person involves a 
change in identity. Moreover, it is implausible to hold that if there is a change in identity, it must occur at a distinct point in time or development. For these reasons, especially the latter, the argument should be rejected.

\section{THE ARGUMENT FROM SUBSTANTIAL IDENTITY}

A second argument is put forward in the personal statement by George and Gómez-Lobo. ${ }^{13}$ This argument, which makes use of the Aristotelian concepts of "essential property" and "active potentiality," has been referred to as the argument from substantial identity. ${ }^{14}$ George and Gómez-Lobo maintain that the developing human organism is a member of the natural kind human being. This membership holds at all stages of development because at all stages the organism possesses the essential characteristic of human beings. This essential property is identified by George and Gómez-Lobo as "the basic natural capacity for characteristically human mental functions." This capacity is a potentiality to develop into an organism that exhibits mental characteristics such as self-consciousness and rationality. It is distinguished by George and Gómez-Lobo from an "immediately exercisable capacity" for self-consciousness and rationality. The latter is the capacity for mental functions that is actually exercised by humans who are far enough advanced in development to exhibit such functions. In their words:

Of course, human beings in the embryonic, fetal, and early infant stages lack immediately exercisable capacies for mental functions characteristically carried out (though intermittently) by most...human beings at later stages of maturity. Still, they possess in radical ( = root) form these very capacities. Precisely by virtue of the kind of entity they are, they are from the beginning actively developing themselves to the stages at which these capacities will (if all goes well) be immediately exercisable....As humans, they are members of a natural kind - the human species - whose embryonic, fetal, and infant members, if not prevented by some extrinsic cause, develop in due course and by intrinsic self-direction the immediately exercisable capacity for characteristically human mental functions. Each new human being comes into existence possessing the internal resources to develop immediately exercisable characteristically human mental capacities - and only the adverse effects on them of other causes will prevent their full development. In this sense, even human beings in the embryonic, fetal, and infant stages have the basic natural capacity for characteristically human mental functions. ${ }^{15}$

The concept of an essential property can be understood for purposes of this discussion as the following: it is a property such that if 
one possesses it at any time that one exists, one possesses it at all times that one exists, and if one loses it, one ceases to exist. An essential property defines the type of substance a thing is. According to the view in question, the type of substance we are is "human being," or to state it differently, we are essentially human beings. ${ }^{16}$ In the view of George and Gómez-Lobo, an equivalent way to state this is to say that we are essentially human organisms, for they hold that the human organism from the zygote stage forward is a human being. They hold that each of us used to be a preembryo because the preembryo from which we developed has the same essential property we have - a basic natural capacity for characteristically human mental functions. ${ }^{17}$

The argument also maintains that all human beings deserve full respect, and because preembryos are human beings, they deserve full respect. As George and Gómez-Lobo put it:

To deny that embryonic human beings deserve full respect, one must suppose that not every whole living human being is deserving of full respect. To do that, one must hold that those human beings who deserve full respect deserve it not in virtue of the kind of entity they are, but, rather in virtue of some acquired characteristic that some human beings (or human beings at some stages) have and others do not, and which some human beings have in greater degree than others. We submit that this position is untenable. ${ }^{18}$

The argument draws upon a distinction between active and passive potentiality, which in turn is based on an interpretation of Aristotle's discussion of potentiality. The term "active potentiality" is used when development of the potential is caused by factors that are internal to the entity undergoing change; by contrast, "passive potentiality" refers to a potential to undergo change as a result of factors that entirely are outside the entity being changed. ${ }^{19}$ Moreover, Aristotle is interpreted as holding that "active potentiality" applies in cases where the identity of the entity undergoing change is preserved throughout the change. ${ }^{20}$ For George and Gómez-Lobo, a "basic natural capacity" is an active potentiality, for, as they state, the human organism has the "internal resources" needed for development. They are referring to the fact that the development process is caused by genetic factors within the organism. The notion that human development is accurately described by the Aristotelian concept of active potentiality is taken to support their claim that identity is preserved across all stages of human development. ${ }^{21}$ 
This argument is a sophisticated version of the "argument from potential." An earlier version of the argument from potential had held that a potentiality for personhood endows any organism possessing such potentiality with personhood even now. ${ }^{22}$ A standard objection to this early version points out that it is based on a logical mistake. If $\mathrm{A}$ is potentially $\mathrm{B}$, then it follows that $\mathrm{A}$ is not $\mathrm{B}$. If preembryos are potential persons, it follows that preembryos are not persons yet. ${ }^{23}$ Thus, the early version clearly is mistaken, but the argument by George and Gómez-Lobo avoids this difficulty. Instead of claiming that self-consciousness gives rise to moral standing and that preembryos have a potential for self-consciousness, it claims that it is the potentiality itself that gives rise to moral standing - that is, the basic natural capacity for characteristically human mental functions is the basis for moral standing. Given this version of the argument from potential, the truth of the statement "If $\mathrm{A}$ is potentially $\mathrm{B}$, then $\mathrm{A}$ is not $\mathrm{B}$ " is beside the point, or at least that is what the proponents of the argument would have us believe.

As before, a critical examination of the argument will be facilitated by laying out the main premises and conclusion. It turns out that there is more than one way to take the ideas in the argument of George and Gómez-Lobo and arrange them into numbered premises. I am going to present two main ways of stating their argument. The first way emphasizes the concept of personal identity:

(1) A human preembryo is the same entity as the adult human being into which it develops.

(2) If an individual is the same entity as a human being, then it is a human being.

(1), (2), therefore:

(3) A human preembryo is a human being.

(4) All human beings deserve full respect.

(3), (4), therefore:

(5) A human preembryo deserves full respect.

A second way that one can state their argument emphasizes the concept of essential property:

(1') A human preembryo possesses the same essential property, a basic natural capacity for characteristically human mental functions, as the adult human being into which it develops.

$\left(2^{\prime}\right)$ Whatever has the same essential property as a human being is a human being. 
$\left(1^{\prime}\right),\left(2^{\prime}\right)$, therefore:

(3') A human preembryo is a human being.

(4') All human beings deserve full respect.

$\left(3^{\prime}\right),\left(4^{\prime}\right)$, therefore:

(5') A human preembryo deserves full respect.

\section{Critique}

Let us turn to a critique of these arguments, beginning with the first version. There is a difficulty with premise (1), which holds that the human preembryo is the same entity as the adult into which it develops. An argument against premise (1) is based on facts about embryological development. At approximately two weeks following fertilization, the preembryo develops into an entity that consists of the embryo proper and the trophoblast. The embryo proper - that is, the embryo - develops from the inner cell mass, which forms into two cell layers during approximately ten to fourteen days after fertilization. These layers initially are shaped roughly like a circular disc, but they progressively become ovoid. At about the fourteenth day, the primitive streak begins to form at one end of the long axis of this ovoid. That end will become the hind-end of the embryonic axis and the opposite will be the fore-end, where development of the head eventually will occur. The formation of the embryo begins with the appearance of this axis. By contrast, the trophoblast is the outer part of the blastocyst, and it is the part of the preembryo that will become placenta and membranes. At the stage in question - when the embryo has begun to be formed - the preembryo is the entire collection of cells consisting of the embryo and the trophoblast. The entity that began as a zygote, then became a two-celled entity, then four-celled, and so on, becomes the entire collection of cells in question. But the embryo is not identical to the entire collection of cells, for it consists of only part of the entire collection. Therefore, the preembryo is not identical to the embryo. Moreover, it is the embryo that develops into the fetus. The placenta and membranes are not part of the fetus. They are extrafetal structures that provide oxygen, nutrition, and protection from infection, among other functions. The preembryo's lack of identity with the embryo entails its lack of identity with the fetus. And if it is not identical to the fetus, then it is not identical to the infant or adult. This lack of identity means that premise (1) is incorrect. This version of the argument by George and Gómez-Lobo is unsuccessful. 
To state it differently, the problem with the metaphysical view upon which premise (1) is based has to do with the nature of the preembryo's potential. One can make a distinction between two senses of potentiality: the potential of an entity to bring about change to itself; and the potential of an entity to change into something else. The view in question interprets the preembryo's potential as the former type - an identity-preserving potential. However, the preembryo's potential to cause the formation of the embryo and trophoblast is the latter type-a nonidentity potential. ${ }^{24}$ This also illustrates the problem with accepting as dogma the view that active potentiality is always identity-preserving. Clearly, the preembryo is not identical to the embryo, and just as clearly the preembryo has an active potentiality, in the sense that its development is controlled primarily from within. Through an active potentiality, the preembryo becomes something that is different from itself.

It might be objected that the trophoblast is part of the embryo and that the placenta and membranes are part of the fetus. On this view, the placenta and membranes are fetal organs and are part of the fetus's body until birth, when they are discarded. Their relationship to the body might be thought of as analogous to hair and nail clippings, which are part of the body until they are clipped. According to this perspective, the postimplantaion embryo is not what embryologists call the embryo, but rather it is the trophoblast together with what embryologists call the embryo. This view permits one to maintain that the preembryo is identical to the embryo, albeit with a new concept of what constitutes the embryo. In reply, although one could adopt this ontological viewpoint, doing so would have a cost, in that it commits one to views that are counterintuitive. Our ordinary way of talking about the fetus and placenta seems to reflect a more intuitive understanding about how to divide the world into separate entities. On this more plausible view, the placenta is a separate structure, which is connected to the fetus by the umbilical cord. If we were to abandon this way of thinking about the fetus and placenta, we would find that we have to make alterations in other areas as well. Consider, for example, those cases of twins in which there is one placenta, to which each twin is attached. ${ }^{25}$ On the view in question, for each twin, the placenta is part of its body. So for every case of twins like this, we would have to think of them as being conjoined twins, since they share part of each other's body. Again, this is counterintuitive; we think of normal twins in such cases as having completely separate bodies. And the view in question would also hold 
that conjoined twins can be surgically separated at birth, albeit by minor surgery, when the umbilical cords are cut. This too is an implausible view, and it underscores the cost of adopting the metaphysics in question - it commits one to views that are at odds with our intuitive way of dividing the world into distinct entities.

Another version of the objection would hold that although the placenta and membranes are not part of the fetus, the trophoblast nevertheless is part of the embryo. On this view, as the trophoblast continues to develop, it eventually gives rise to a new entity, the placenta and membranes. This view permits one to hold that the entity that develops into the fetus is the combination of the trophoblast and what embryologists call the embryo. This allows one to claim that the preembryo is identical to the fetus and that the placenta and membranes are a separate entity. In reply, this version also commits one to views that are counterintuitive. For one thing, it is at odds with the standard, and highly plausible, view that the embryo (that is, what embryologists call the embryo) develops into the fetus and that the trophoblast develops into the placenta and membranes. The view in question holds, rather, that the combination of the trophoblast and what embryologists call the embryo develops into the fetus and that the trophoblast also develops into the placenta and membranes. This view is confusing and is less straightforward and intuitive than the standard view. Another problem arises from the fact that in some cases involving identical twins, two embryonic discs arise from the inner cell mass. The view in question commits one to saying that, even though the discs are separate and distinct, they are in fact conjoined twins, because the trophoblast is part of each. It also commits one to saying that later in development, when the placenta(s) and membranes become separate entities, the twins cease being conjoined. This is an unnecessarily complicated and odd way to describe the entities in question.

Let us turn to the second version of George and Gómez-Lobo's argument. In this version, a serious problem arises concerning premise $\left(1^{\prime}\right)$. This premise asserts that normal human adults have a basic natural capacity for characteristically human mental functions. It seems clear that George and Gómez-Lobo embrace this idea. After all, they hold that the human organism at all stages of development possesses a basic natural capacity for characteristically human mental functions. That they regard this basic natural capacity as a potentiality is made clear in the following passage, which discusses the difference between a basic natural capacity and an immediately exercisable capacity: 
...the difference between these two types of capacity is merely a difference between stages along a continuum. The proximate, or immediately exercisable, capacity for mental functions is only the development of an underlying potentiality that the human being possesses simply by virtue of the kind of entity it is. ${ }^{26}$

Thus, in their view all human beings, including adults, possess the potentiality to develop an immediately exercisable capacity for selfconsciousness. The fact that their argument implies this is hidden from view, to some extent, by the fact that they usually use the term "capacity" as a substitute for the term "potentiality." But indeed, the argument from substantial identity implies that normal human adults have a potential to become self-conscious. That implication seems rather odd. If Professor George were to walk into class and announce that he has the potential to become self-conscious, his students would hardly know what to make of that comment; perhaps they would think that he is making a joke, because the statement implies that he is not self-conscious. As pointed out above, it is indeed part of the logic of the term "potentiality" that if A has the potentiality to become $\mathrm{B}$, then $\mathrm{A}$ is not $\mathrm{B}$. However, the argument from substantial identity asserts that normal human adults, like normal human preembryos, possess a potentiality to become self-conscious individuals. But the fact is, normal human adults do not have such a potentiality - they are self-conscious. In their case, potentiality has become actuality.

So, it turns out that the logical point remains relevant. Moreover, it is clear that the logical point is correct, and we can see this simply by considering an example. For A let us substitute "a human preembryo," and for B let us substitute "an individual with an immediately exercisable capacity for characteristically human mental functions." Clearly, a human preembryo with a basic natural capacity (a potential) to become an individual with an immediately exercisable capacity for characteristically human mental functions is not now an individual with that immediately exercisable capacity.

To underscore the objection I am making, let us keep the same substitution for B as above. This yields the following true statement:

If A has the potentiality to become an individual with an immediately exercisable capacity for characteristically human mental functions, then $\mathrm{A}$ is not an individual with an immediately exercisable capacity for characteristically human mental functions.

For A let us now substitute "a normal awake human adult." In this material implication, if we consider the consequent alone 
(a normal awake human adult is not an individual with an immediately exercisable capacity for characteristically human mental functions), we see that the consequent is false. If we apply modus tollens, ${ }^{27}$ we obtain:

It is false that a normal awake human adult has the potentiality to become an individual with an immediately exercisable capacity for characteristically human mental functions.

Therefore, it is not true that preembryos and adults have in common the "basic natural capacity for characteristically human mental functions." Hence, premise $\left(1^{\prime}\right)$ is false, and moreover, the metaphysics that is based on the notion that preembryos and adults alike have this property is mistaken. ${ }^{28}$

\section{ADDITIONAL ARGUMENTS BY GEORGE AND GOMEZ-LOBO}

George and Gómez-Lobo give several arguments in defense of the view that moral standing is based on possession of the basic natural capacity, as opposed to the immediately exercisable capacity, for characteristically human mental functions. Let us turn to an examination of those arguments.

\section{Argument from the moral standing of infants}

George and Gómez-Lobo point out that infants do not have an immediately exercisable capacity for the sort of mental functions in question, and they claim that grounding moral standing on an immediately exercisable capacity rather than a basic natural capacity commits one to the view that infants do not have moral standing. ${ }^{29}$ One problem with this argument is that George and Gómez-Lobo mischaracterize the views of their opponents. Those who hold that moral standing arises later in development do not generally hold that self-consciousness must be immediately exercisable in order for one to have moral standing. Such a view does not account for those who have previously been self-conscious but now are reversibly unconscious, such as those who are asleep, anesthetized, or reversibly comatose. Even putting aside this mischaracterization, the argument is unsuccessful because it assumes that the only way to justify the moral standing of an individual is by appeal to inherent characteristics. This assumption overlooks the distinction between intrinsic 
and conferred moral standing. ${ }^{30}$ Self-conscious individuals are ends in themselves in the literal sense that they have the ability to choose their own ends, plans, and values. These inherent characteristics give them what is called intrinsic moral standing. A number of authors have argued that it is justifiable to confer full moral standing upon infants although they lack the inherent characteristics upon which intrinsic moral standing is based. ${ }^{31}$ These authors generally argue that infants are similar enough, in morally relevant ways, to individuals who have intrinsic moral standing to justify conferring full moral standing upon them. Thus, George and Gomez-Lobo are mistaken in implying that those who reject their view are committed to holding that infants lack full moral standing.

\section{Argument from degree of development}

George and Gómez-Lobo claim that the difference between a preembryo and an adult is that the adult's basic natural capacity is more developed than the preembryo's. The degree of development of this capacity can be regarded as a feature of the developing human. The degree of development increases gradually, and the adult has more of this feature than the preembryo. George and Gómez-Lobo maintain that a difference in moral standing cannot be based on the fact that one has more of this feature than the other. In their words:

A mere quantitative difference (having more or less of the same feature, such as the development of a basic natural capacity) cannot by itself be a justificatory basis for treating different entities in radically different ways. Between the ovum and the approaching thousands of sperm, on the one hand, and the embryonic human being, on the other hand, there is a clear difference in kind. But between the embryonic human being and that same human being at any later stage of its maturation, there is only a difference in degree. ${ }^{32}$

In reply, let me put aside the problem, pointed out above, that it is false to claim that self-conscious humans have the potential to become self-conscious. The point to be made here is that the justificatory argument George and Gómez-Lobo attribute to their opponents is not in fact the argument that the opponents make. The opponents claim that the difference in moral standing is based on the fact that adults possess characteristics that preembryos lack, not that they possess some feature to a greater degree. Moreover, let us assume for sake of argument that adults have the feature in question (i.e., development of the basic natural capacity) to a greater degree than preembryos. Because their opponents do not assert the 
argument in question, the most that George and Gómez-Lobo can reasonably claim is that it is an implication of their opponents' position that some individuals with full moral standing possess the feature to a greater degree than some individuals that lack full moral standing. But there is nothing wrong with this implication. It seems clear that some individuals with full moral standing possess some characteristics to a greater degree than some individuals that lack full moral standing. Consider a cross-species comparison. Different animal species have a capacity for mental functions, although the magnitude of the developed capacity in adults is greater for some species than for others. We can describe this by saying that the capacity differs in degree across species. Adult humans have a capacity for mental functions to a greater degree than adult cats, for example. Moreover, adult humans have full moral standing and cats do not. Thus, individuals with full moral standing can possess some characteristics to a greater degree than some individuals that lack full moral standing. ${ }^{33}$

\section{Argument from degrees of self-consciousness}

George and Gómez-Lobo claim that the immediately exercisable capacity in question admits of degrees - that different humans possess different degrees of self-consciousness, intelligence, and rationality. If moral standing is based on a capacity that admits of degrees, they claim, then "no account could be given of why basic rights are not possessed by human beings in varying degrees" and therefore some self-conscious people would have higher moral standing and stronger rights than others. ${ }^{34}$ In reply, those who hold that intrinsic moral standing is based on the possession of selfconsciousness hold that all individuals who reach a minimum threshhold of self-consciousness have inherent moral standing and have it to the same degree. The claim by George and Gómez-Lobo that no account can be given in support of this threshhold concept is simply false. A number of commentators have provided such accounts. For some, a key concept is moral agency. All who meet the threshhold are moral agents and, as such, are members of the moral community with equal claim to moral standing. ${ }^{35}$ Others emphasize the concept of being an end in oneself. All who meet the threshhold are ends in themselves because they have the ability to choose their own ends. ${ }^{36}$ 


\section{CONCLUSION}

It is good that those who hold the right-to-life view concerning human preembryos attempt to formulate, in secular terms, arguments in support of their view; doing so permits a dialogue concerning the reasonableness of opposing views. I have presented objections to the argument based on identity through biological continuity and the argument from substantial identity. These objections point to serious problems with the arguments and show that neither argument is successful. The lack of identity between the preembryo and the human organism at later stages of development is especially significant for stem cell research. Stem cells, to date at least, are derived from preembryos, not embryos. The main arguments for preembryo personhood rely on an identity that does not exist. This means that no reasonable secular arguments have been made supporting the view that it is wrong to obtain stem cells from preembryos.

\section{NOTES}

1 In the debate over stem cell research, the term "embryo" is often used, and reference is made to the destruction of embryos. In this paper, I use the term "preembryo" to refer to the conceptus from the time of fertilization until the formation of the primitive streak, at approximately fourteen days following fertilization. By contrast, the embryo proper begins to exist with the formation of the embryonic plate and the primitive streak. The need to distinguish the preembryo from the embryo proper will become apparent later in the essay.

2 Carson Strong, "Those Divisive Stem Cells: Dealing with Our Most Contentious Issues," American Journal of Bioethics 2 (Winter 2002): 39-40.

3 Elizabeth Blackburn, "Bioethics and the Political Distortion of Biomedical Science," New England Journal of Medicine 350 (2004): 1379-1380.

4 The President's Council on Bioethics, Monitoring Stem Cell Research (Washington, D.C., 2004), p. 54.

5 Robert P. George and Alfonzo Gómez-Lobo, "Statement of Professor George (Joined by Dr. Gómez-Lobo)," in The President's Council on Bioethics, Human Cloning and Human Dignity: An Ethical Inquiry (Washington, D.C., 2002), pp. 258-266.

6 President's Council, Monitoring Stem Cell Research, cited in n. 4 above, p. 76.

7 President's Council, Monitoring Stem Cell Research, cited in n. 4 above, pp. 76-77.

8 When I use the expression "a change in identity," I refer to the ceasing to exist of one entity and the coming into being of another entity.

9 These concepts can be found in David Wiggins, Sameness and Substance (Cambridge, MA: Harvard University Press, 1980), p. 24. Instead of "phase sortal" and "proper sortal," Wiggins uses the terms "phased-sortal" and "substance-concept."

10 Dean Stretton, "The Argument from Intrinsic Value: A Critique," Bioethics 14 (2000): 228-239, at 233. 
11 Warren Quinn, “Abortion: Identity and Loss," Philosophy and Public Affairs 13 (1984): 24-54, at 35. Similarly, Lawrence Becker holds that "entry into the class of human beings is a process," in "Human Being: The Boundaries of the Concept," Philosophy and Public Affairs 4 (1975): 334-359, at 335.

12 These sorts of questions are raised by Warren Quinn, cited in n. 11 above, pp. 34-39.

13 George and Gómez-Lobo, cited in n. 5 above.

14 See, e.g., Patrick Lee, "The Pro-Life Argument from Substantial Identity: A Defense," Bioethics 18 (2004): 249-263.

15 George and Gómez-Lobo, cited in n. 5, above, p. 260.

16 Explicit use of the Aristotelian term "substance" and the distinction between "essential" and "accidental" characteristics is not made in the personal statement (note 5 above), but can be found in Robert P. George and Patrick Lee, "Acorns and Embryos," The New Atlantis, 7 (Fall 2004/Winter 2005): 90-100, at 94; and Robert P. George, "The Ethics of Embryonic Stem Cell Research and Human Cloning," Family Research Council: Defending Faith, Family, and Freedom, Issue No. 87, available at http://www.frc.org/get.cfm?I $=$ PD02D5\&v $=$ PRINT, at p. 7 of 10 .

17 George and Gómez-Lobo use the term "embryo" rather than "preembryo."

18 George and Gómez-Lobo, cited in n. 5, above, pp. 259-260.

19 See, e.g., Alfonso Gómez-Lobo, "On Potentiality and Respect for Embryos: A Reply to Mary Mahowald," Theoretical Medicine and Bioethics 26 (2005): 105-110, at 106 .

20 See, e.g., Massimo Reichlin, "The Argument from Potential: A Reappraisal," Bioethics 11 (1997): 1-23, at 4; Jason T. Eberl, "Aquinas's Account of Human Embryogenesis and Recent Interpretations," Journal of Medicine and Philosophy 30(2005): 379-394.

21 Others argue in a similar manner. See, e.g., Reichlin, cited in note 20 above. See also A. Chadwick Ray, "Humanity, Personhood and Abortion," International Philosophical Quarterly 25 (1985): 233-245; Robert E. Joyce, "Personhood and the Conception Event," The New Scholasticism 52 (1978): 97-109. The term "basic natural capacity" need not be interpreted as implying that the cause of change is entirely internal, but can be understood as implying only that the cause has a very significant internal component. After all, the development of the preembryo into an adult is not caused by factors entirely inside the organism. For example, a woman's uterus is necessary, and the embryo proper is nourished and oxygenated by the placenta. Proponents of the argument in question recognize that there are external as well as internal causes in embryogenesis. See, e.g., Gómez-Lobo, cited in n. 19 above, p. 106.

22 For a statement of the earlier version, see, e.g., Reichlin, cited in n. 20 above, pp. 1-2. See also Peter Singer, Practical Ethics (Cambridge, UK: Cambridge University Press, 1979), p. 119.

23 See, e.g., H. Tristram Engelhardt, Jr., The Foundations of Bioethics (New York: Oxford University Press, 1986), p. 111.

24 A similar distinction is made by Stephen Buckle, who refers to the two types of potential as "potential to become" and "potential to produce," in "Arguing from Potential," Bioethics 2 (1988): 227-253. I use the terms "identity-preserving potential" and "nonidentity potential" from Jeff McMahan, The Ethics of Killing: Problems at the Margins of Life (Oxford: Oxford University Press, 2002), p. 304. 
25 A single placenta can be present in cases involving monozygotic ("identical") or dizygotic ("fraternal") twins. When monozygotic twins result from cleavage of the preembryo during approximately three to eight days after fertilization, having a single placenta is a common occurrence. When cleavage occurs soon after the eighth day, there can also be a single set of membranes, referred to as monoamniotic and monochorionic twins. See, e.g., F. Gary Cunningham, Paul C. McDonald, Norman F. Gant, et al., Williams Obstetrics, 20th Edition (Stamford, CT: Appleton \& Lange, 1997), pp 861-863.

26 George and Gómez-Lobo, cited in n. 5 above, p. 261, emphasis added.

27 The form of argument, modus tollens, is as follows:

if $\mathrm{p}$, then $\mathrm{q}$

$\sim \mathrm{q}$

therefore

$\sim \mathrm{p}$

28 There is an argument by Gómez-Lobo that might be regarded as a reply to this objection. In discussing the logical point in question - if A is potentially $\mathrm{B}$, then $\mathrm{A}$ is not $\mathrm{B}$ - he claims that this point might not always be true. He suggests that its truth might depend on whether $\mathrm{B}$ is a phase sortal or a proper sortal. He claims that if the substitution for B is a phase sortal, then the logical point is true. But if the substitution for B is a proper sortal, he states, "it is not clear whether the dictum is true or not...." See Alfonso Gómez-Lobo, "Does Respect for Embryos Entail Respect for Gametes?" Theoretical Medicine 25 (2004): 199-208, at 205.

In reply, if we assume for sake of argument that these claims by Gómez-Lobo are correct, they do not constitute a rebuttal to the objection in question. The reason is that, in Gómez-Lobo's own view, what I have substituted for B in the above argument - "an individual with an immediately exercisable capacity for characteristically human mental function" - is a phase sortal. He holds that the immediately exercisable capacity is an accidental property, not an essential property. Thus, in his view, the "dictum," as I use it in the example in the text, is true.

In his attempt to reject the logical point, Gómez-Lobo also makes the following argument:

In other words, if A is potentially B (a thinking and self-conscious being) it does not follow that A is not B. It follows that it is indeed B (a thinking and conscious being), but surely not a fully developed one. If we should respect $\mathrm{B}$, then we should also respect $\mathrm{A}$ because it has the same properties that lead us to respect $\mathrm{B}$, only at an earlier stage of development. The potentiality of an embryo, then, is not the potentiality to become a person. It is the potentiality of a person fully to actualize the capacities that we associate with adult persons. (pp. 205-206)

In reply, the argument in the above passage is fallacious. The problem is that there is an equivocation of the expression "a thinking and self-conscious being." In the sense in which $\mathrm{A}$ is potentially $\mathrm{B}$, the expression is being used as equivalent to something like "an individual who is a thinking and self-conscious being." In the sense in which $\mathrm{A}$ is $\mathrm{B}$, the expression is equivalent to something like " $a$ type of being adult members of which are thinking and self-conscious." Using the former meaning, if A is potentially B, then A is not B. For Gómez-Lobo simply to assert 
otherwise would be question begging, for this is the very proposition he is trying to disprove. Using the latter meaning, if $\mathrm{A}$ is $\mathrm{B}$, then (by modus tollens) $\mathrm{A}$ is not potentially B. Again, it would be question begging for Gómez-Lobo simply to assert otherwise. Neither meaning makes it true both that A is potentially B and that $\mathrm{A}$ is $\mathrm{B}$.

${ }^{29}$ George and Gómez-Lobo, cited in note 5 above, p. 261.

30 A number of commentators have made a distinction between intrinsic and conferred moral standing, although this terminology is not uniformly used. See, e.g., Engelhardt, cited in note 23 above, pp. 104-109, 116; Roger Wertheimer, "Philosophy on Humanity," in Robert L. Perkins, ed., Abortion: Pro and Con (Cambridge, MA: Schenkman, 1974), pp. 107-128; Ronald M. Green, "Conferred Rights and the Fetus," Journal of Religious Ethics 2 (1974): 55-75.

31 See S. I. Benn, "Abortion, Infanticide, and Respect for Persons," in The Problem of Abortion, 2d ed., ed. Joel Feinberg (Belmont, CA: Wadsworth, 1984), pp. 135-144, at 143; Joel Feinberg, "Potentiality, Development, and Rights," in Problem of Abortion, ed. Joel Feinberg, pp. 145-150, at 149; Mary Anne Warren, "The Moral Significance of Birth," Hypatia 4 (1989): 46-65, at 56-57; Green, cited in note 30 above; Jane English, "Abortion and the Concept of a Person," Canadian Journal of Philosophy 5 (1975): 233-243, at 241; Engelhardt, cited in note 23 above, p. 117; Carson Strong, Ethics in Reproductive and Perinatal Medicine: A New Framework (New Haven: Yale University Press, 1997), pp. 53-62.

32 George and Gómez-Lobo, cited in note 5 above, p. 261.

33 My argument draws upon comments by Dean Stretton, "Essential Properties and the Right to Life: A Resonse to Lee," Bioethics 18 (2004): 264-282, at 269-270.

${ }^{34}$ George and Gómez-Lobo, cited in note 5 above, p. 262.

35 Authors who appear to have something like this in mind include: Green, cited in note 30 above; Bernard Gert, The Moral Rules: A New Rational Foundation for Morality (New York: Harper Torchbooks, 1973); John Rawls, A Theory of Justice (Cambridge, MA: Harvard University Press, 1971).

${ }^{36}$ Commentators who seem to take an approach along this line include: Engelhardt, cited in note 23 above; Strong, cited in note 31 above.

\section{REFERENCES}

Becker, L. "Human Being: The Boundaries of the Concept." Philosophy and Public Affairs 4 (1975): 334-359.

Benn, S.I. "Abortion, Infanticide, and Respect for Persons." In: The Problem of Abortion, 2nd ed. Edited by Joel Feinberg. 135-144. Belmont, CA: Wadsworth, 1984.

Blackburn, E. "Bioethics and the Political Distortion of Biomedical Science." New England Journal of Medicine 350 (2004): 1379-1380.

Buckle, S. “Arguing from Potential.” Bioethics 2 (1988): 227-253.

Cunningham, F.G., P.C. McDonald and N.F. Gant, Williams Obstetrics (20th ed.). Stamford, CT: Appleton \& Lange, 1997. 
Eberl, J.T. “Aquinas's Account of Human Embryogenesis and Recent Interpretations." Journal of Medicine and Philosophy 30 (2005): 379-394.

Engelhardt, H.T. Jr The Foundations of Bioethics. New York: Oxford University Press, 1986.

English, J. "Abortion and the Concept of a Person." Canadian Journal of Philosophy 5 (1975): 233-243.

Feinberg, J. "Potentiality, Development, and Rights." In The Problem of Abortion, 2nd ed. Edited by Joel Feinberg. 145-150. Belmont, CA: Wadsworth, 1984.

George, R.P. "The Ethics of Embryonic Stem Cell Research and Human Cloning." Family Research Council: Defending Faith, Family, and Freedom, Issue No. 87. May 23, 2002. Available at http://www.frc.org/get.cfm?I=PD02D5\&v=PRINT.

George, R.P and A. Gómez-Lobo. "Statement of Professor George (Joined by Dr. Gómez-Lobo)." In Human Cloning and Human Dignity: An Ethical Inquiry. The President's Council on Bioethics. Washington, D.C., 2002. Available at http:// www.bioethics.gov.

George, R.P and P. Lee. "Acorns and Embryos." The New Atlantis 7 Fall 2004/ Winter 2005:90-100.

Gómez-Lobo, A. "Does Respect for Embryos Entail Respect for Gametes?." Theoretical Medicine 25 (2004): 199-208.

Gómez-Lobo, A. "On Potentiality and Respect for Embryos: A Reply to Mary Mahowald." Theoretical Medicine and Bioethics 26 (2005): 105-110.

Green, R.M. "Conferred Rights and the Fetus." Journal of Religious Ethics 2 (1974): $55-75$.

Joyce, R.E. "Personhood and the Conception Event." The New Scholasticism 52 (1978): 97-109.

Lee, P. "The Pro-Life Argument from Substantial Identity: A Defense." Bioethics 18 (2004): 249-263.

McMahan, J. The Ethics of Killing: Problems at the Margins of Life. Oxford: Oxford University Press, 2002.

President's Council on Bioethics. Monitoring Stem Cell Research. Washington, D.C., 2004. Available at http://www.bioethics.gov.

Quinn, W. "Abortion: Identity and Loss." Philosophy and Public Affairs 13 (1984): $24-54$.

Ray, A.C. "Humanity, Personhood and Abortion." International Philosophical Quarterly 25 (1985): 233-245.

Reichlin, M. "The Argument from Potential: A Reappraisal." Bioethics 11 (1997): $1-23$.

Singer, P. Practical Ethics. Cambridge: Cambridge University Press, 1979.

Stretton, D. "The Argument from Intrinsic Value: A Critique." Bioethics 14 (2000): $228-239$.

Stretton, D. "Essential Properties and the Right to Life: A Response to Lee." Bioethics 18 (2004): 264-282.

Strong, C. Ethics in Reproductive and Perinatal Medicine: A New Framework. New Haven: Yale University Press, 1997.

Strong, C. "Those Divisive Stem Cells: Dealing with Our Most Contentious Issues." American Journal of Bioethics 2 (2002): 39-40, Winter.

Warren, M.A. "The Moral Significance of Birth." Hypatia 4 (1989): 46-65. 
Wertheimer, R. "Philosophy on Humanity." In: Abortion: Pro and Con. Edited by Robert L. Perkins 107-128. Cambridge, MA: Schenkman, 1974.

Wiggins, D. Sameness and Substance. Cambridge, MA: Harvard University Press, 1980.

Department of Human Values and Ethics, College of Medicine University of Tennessee

956 Court Avenue, Suite B 324

Memphis, Tennessee 38163

United States

E-mail: cstrong@utmem.edu 